\title{
Polymorphisms in reverse transcriptase and protease genes of HIV-1 subtype C from Mumbai
}

\author{
Ritwik Dahake*, Shraddha Mehta, Sneha Yadav, Abhay Chowdhary, Ranjana A Deshmukh \\ From 2nd International Science Symposium on HIV and Infectious Diseases (HIV SCIENCE 2014) \\ Chennai, India. 30 January - 1 February 2014
}

\section{Background}

Primary or transmitted HIV-1 drug resistance has caused an alarm in developed countries. While certain HIV-1 subtype $\mathrm{C}$ polymorphisms in relation to consensus subtype $\mathrm{B}$ sequences are known, there still exists a debate on the validity of these mutations being associated with/mistaken as, primary resistance. In this preliminary study, we have determined polymorphisms in reverse transcriptase (RT) and protease (PR) genes of HIV-1 subtype C from Mumbai, India.

\section{Methods}

The study was performed using plasma samples from 24 antiretroviral therapy-experienced and drug-naïve patients employing a 'home-brew' semi-nested reversetranscriptase-PCR followed by sequencing and sequence analysis. Analysis and interpretation of polymorphisms and other drug-resistance mutations was carried out using the Stanford HIV drug-resistance database. We also analysed Surveillance Drug Resistance Mutations (SDRMs) for PR gene.

\section{Results}

We determined polymorphisms at a mutational frequency of $0.0670 \pm 0.014$ and $0.1337 \pm 0.042$, while $12.5 \%$ and $16.6 \%$ samples harboured drug-resistance mutations in RT and PR genes respectively. Substitutions greater than $50 \%$ were at positions D121, K122, T165, K166, K173, D177, T200, Q207, R211 for RT and L19, V82, M36, R41, L63, H69, L89, I93 for PR gene. Additionally, PR gene SDRMs were observed in 15.0\% samples.

\section{Conclusion}

Our study re-iterates that polymorphisms in HIV-1 subtype $C$ from India may also include a number of major and minor/accessory mutations associated with resistance. We recommend that HIV subtype-specific drugresistance databases be created to empower routine and unambiguous surveillance of drug resistance prior to initiating antiretroviral therapy, especially when including Protease Inhibitors.

Published: 27 May 2014

doi:10.1186/1471-2334-14-S3-E11

Cite this article as: Dahake et al:: Polymorphisms in reverse transcriptase and protease genes of HIV-1 subtype C from Mumbai. BMC Infectious Diseases 2014 14(Suppl 3):E11.

* Correspondence: ritwikdahake@gmail.com

Department of Virology, Haffkine Institute, Mumbai-400012, Maharashtra, India

Submit your next manuscript to BioMed Central and take full advantage of:

- Convenient online submission

- Thorough peer review

- No space constraints or color figure charges

- Immediate publication on acceptance

- Inclusion in PubMed, CAS, Scopus and Google Scholar

- Research which is freely available for redistribution
() Biomed Central
C Biomed Central

(0) 2014 Dahake et al; licensee BioMed Central Ltd. This is an Open Access article distributed under the terms of the Creative Commons Attribution License (http://creativecommons.org/licenses/by/4.0), which permits unrestricted use, distribution, and reproduction in any medium, provided the original work is properly cited. The Creative Commons Public Domain Dedication waiver (http:// creativecommons.org/publicdomain/zero/1.0/) applies to the data made available in this article, unless otherwise stated. 